Published in final edited form as:

Org Lett. 2006 February 2; 8(3): 427-430.

\title{
Synthetic Studies on Amphidinolide B1
}

Amit K. Mandal ${ }^{\dagger}$, John S. Schneekloth Jr. ${ }^{\ddagger}$, Kouji Kuramochi ${ }^{\dagger}$, and Craig M. Crews ${ }^{\star}, \dagger, \ddagger, \S$

$\dagger$ Department of Molecular, Cellular, and Developmental Biology, Yale University, New Haven, Connecticut 06520-8103

\$Department of Chemistry, Yale University, New Haven, Connecticut 06520-8103

§Department of Pharmacology, Yale University, New Haven, Connecticut 06520-8103

\begin{abstract}
The syntheses of three fragments, 2, 3, and 4, of amphidinolide B1 have been accomplished. The 1,3-isomerization of allylic alcohol 10 was accomplished via rhenium oxo catalysis and has been applied successfully in the synthesis. (-)-MIB-catalyzed asymmetric vinylzinc addition to aldehyde 31 and the regio- and stereoselective epoxidation of unsymmetrical divinyl methanol 32 were key steps.
\end{abstract}

Amphidinolide B1 (1), a polyketide-based 26-membered macrolide, was isolated from a culture of the symbiotic marine dinoflagellate Amphidinium sp. (strain Y-5) in 1987 by Kobayashi et al. 1,2 There have been several reports of partial syntheses toward $\mathbf{1}$; however, no completed total synthesis has been disclosed yet. ${ }^{3}$

In our laboratory, we undertook a multipronged approach toward the synthesis of amphidinolide B1 (1) (Scheme 1). One strategy was communicated earlier, ${ }^{4}$ whereas this paper represents an alternative strategy. Our previous strategy involved three major $\mathrm{C}-\mathrm{C}$ bondforming reactions and one $\mathrm{C}-\mathrm{O}$ bond-forming reaction. This new retrosynthetic analysis involves two $\mathrm{C}-\mathrm{C}$ and one $\mathrm{C}-\mathrm{O}$ bond-forming coupling reactions: Suzuki-Miyaura coupling, 5 an aldol reaction, ${ }^{6}$ and macrolactonization using the three fragments $\mathbf{2}, \mathbf{3}$, and $\mathbf{4}$. As $\mathrm{C}-\mathrm{C}$ bond-forming reactions are traditionally more difficult than $\mathrm{C}-\mathrm{O}$ bond-forming reactions, we hope that this new strategy will increase the efficiency of the synthesis.

The synthesis of fragment 2 began with Brown's crotylation reaction (Scheme 2). ${ }^{7}$ The reaction of trans-crotonaldehyde and $(E)$-crotyldiisopinocamphenylborane (prepared from transbutene, $n$ - $\mathrm{BuLi}, t-\mathrm{BuOK}$, and (+)- $\left.\mathrm{Ipc}_{2} \mathrm{BOMe}\right)$ in the presence of $\mathrm{BF}_{3} \cdot \mathrm{OEt}_{2}$ in THF-Et $2 \mathrm{O}$ at -78 ${ }^{\circ} \mathrm{C}$ produced the allyl alcohol 6 in 50\% yield and 14:1 anti/syn selectivity. Silyl protection of the hydroxyl group and a regioselective hydroboration-oxidation sequence furnished alcohol 7, which was oxidized to the corresponding aldehyde 8 using Dess-Martin periodinane. The asymmetric methylation of $\mathbf{8}$ with $\mathrm{Me}_{2} \mathrm{Zn}$ and $\mathrm{Ti}\left(\mathrm{O}^{i} \mathrm{Pr}\right)_{4}$ was examined with the chiral ligands BINOL and bissulfonamide. ${ }^{8}$ Unfortunately, the conversions were unacceptable in both cases (25\% and 29\%, respectively). However, diastereoselective methylation to obtain 9 was achieved with Seebach's method ${ }^{9}\left[\mathrm{Me}_{2} \mathrm{Zn}\right.$ and $\mathrm{Ti}\left(\mathrm{O}^{i} \mathrm{Pr}\right)_{4}$ in the presence of (-)-TADDOL] in $92 \%$ yield and a 5-7:1 diastereomeric ratio (based on ${ }^{1} \mathrm{H}$ NMR). Protection of the free alcohol as a TIPS ether (the minor isomer can be separated at this stage) and selective cleavage of the allylic TBS ether furnished $\mathbf{1 0}$ in $\mathbf{7 0 \%}$ yield over two steps. At this point, the stage was set to

craig.crews@yale.edu.

Supporting Information Available: Experimental procedures and spectroscopic data. This material is available free of charge via the Internet at http://pubs.acs.org. 
manipulate allylic alcohol $\mathbf{1 0}$ to the requisite $\alpha, \beta$-unsaturated ketone $\mathbf{1 2}$ and to install the remaining stereogenic centers. The 1,3-isomerization of $\mathbf{1 0}$ and subsequent oxidation promised to be an atom-efficient method to access ketone $12 . \mathrm{Ph}_{3} \mathrm{SiOReO}_{3} 10$ is currently the most effective catalyst for 1,3-isomerization. ${ }^{11}$ When we treated $\mathbf{1 0}$ in the presence of $1 \mathrm{~mol} \%$ catalyst in ether at $-60^{\circ} \mathrm{C}$, complete isomerization to regioisomeric allylic alcohol $\mathbf{1 1}$ was observed in $5 \mathrm{~min}$. Oxidation of the alcohol $\mathbf{1 1}$ under Dess-Martin periodinane conditions furnished the $\alpha, \beta$-unsaturated ketone 12. Swapping TIPS protection with TBS, Sharpless asymmetric dihydroxylation ${ }^{12}$ followed by acetonide formation completed the synthesis of fragment 2 .

The synthesis of fragment 3 started with known vinyl iodide $\mathbf{1 3}^{13}$ (Scheme 3). Transmetalation with $t$ - $\mathrm{BuLi}$ in $\mathrm{Et}_{2} \mathrm{O}$ and capture of the resulting vinyllithium species with acetaldehyde yielded $( \pm)$-allylic alcohol 14. Sharpless kinetic resolution ${ }^{14}$ of $( \pm)-14$ gave the desired epoxide 15 in 85-90\% enantiomeric excess (ee) and unreacted alcohol in 25-30\% ee as a mixture that proved difficult to separate. The crude mixture was subjected to a Parikh-Doering oxidation to yield easily separable epoxy ketone $\mathbf{1 6}$ and the corresponding $\alpha, \beta$-unsaturated ketone (not shown). The $\alpha, \beta$-unsaturated ketone was subjected to a Luche reduction to produce ( \pm )-allylic alcohol 14, which was recycled under Sharpless kinetic resolution conditions. The Horner-

Wadsworth-Emmons condensation of epoxy ketone $\mathbf{1 6}$ with phosphonate in the presence of NaHMDS produced enyne 17 [82\% yield, E/Z 6:1]. Simultaneous cleavage of TBS ether and the TMS group by TBAF followed by regioselective opening of the epoxide in the presence of $\mathrm{LiAlH}_{4}$ in $\mathrm{Et}_{2} \mathrm{O}$ furnished diol 18, which was separated from the minor $(Z)$ isomer using column chromatography. Functionalization of the enyne $\mathbf{1 8}$ to the 1,3-diene iodide was quite problematic. After exploring several possibilities, we found that the triple bond could be silylstannylated regio- and stereoselectively employing $n-\mathrm{Bu}_{3} \mathrm{SnSiMe}_{2} \mathrm{Ph} / \mathrm{Pd}\left(\mathrm{PPh}_{3}\right)_{4}$ to produce functionalized diene 19. ${ }^{15} \mathrm{TBAF}-$ mediated removal of the $\mathrm{PhMe}_{2} \mathrm{Si}$ group produced stannane 20. Reaction with $I_{2}$ and selective TBS protection completed the synthesis of fragment 3.

The synthesis of fragment 4 began with aldehyde 21 (Scheme 4). A nonchelation-controlled $\mathrm{S}_{\mathrm{E}} 2^{\prime}$ reaction between aldehyde 21 and methallylsilane in the presence of $\mathrm{BF}_{3} \cdot \mathrm{OEt}_{2}$ furnished homoallylic alcohol 22 in $90 \%$ yield and $\geq 95: 5$ diastereomeric ratio (dr). ${ }^{16}$ Hydroxyl group protection as a TBS ether $\mathbf{2 3}$, followed by oxidative deprotection of the PMB ether, revealed the primary alcohol. The alcohol was then converted to the aldehyde, which was subjected to vinyl-magnesium bromide addition to provide allyl alcohol $\mathbf{2 4}$ as a 1.5:1 diastereomeric mixture (based on ${ }^{1} \mathrm{H}$ NMR). The allylic alcohol 24 underwent Johnson ortho ester Claisen rearrangement to provide the homologated ethyl ester exclusively as the $(E)$ isomer. Reduction to the aldehyde using $i$ - $\mathrm{Bu}_{2} \mathrm{AlH}$ in THF and the Wittig reaction furnished fragment $\mathbf{4}$ with exclusive $(E)$ selectivity.

With all three fragments securely in hand, we sought to explore the possibility of setting up the $\mathrm{C} 11$ stereogenic centers by hydroboration and a subsequent $(B)$-alkyl Suzuki-Miyaura coupling reaction ${ }^{5}$ to assemble the 1,3-diene. We hoped to induce 1,3-stereocontrol on the basis of Evans' alkyl-directed hydroboration model. ${ }^{17}$ We have been able to form the C12$\mathrm{C} 13$ bond successfully using the $(B)$-alkyl Suzuki-Miyaura coupling reaction between $(B)$ alkylborane (derived from regioselective hydroboration of fragment 4 ) and ( \pm )-1,3-vinyl iodide fragment 3 (synthesis not shown) to put together the $\mathrm{C} 1-\mathrm{C} 18$ portion of the molecule. However, investigations revealed that 1,3 -stereocontrol cannot be achieved with this substrate, as hydroboration of fragment $\mathbf{4}$ with 9-BBN provided a 1:1 inseparable mixture of diastereoisomers at C11 (amphidinolide B1 numbering).

Considering A values, an alkyl group (i.e., $\mathrm{Me}=1.74 \mathrm{kcal} / \mathrm{mol}$ ) imparts more nonbonding interaction than an $\mathrm{OSiR}_{3}$ group (i.e., $\mathrm{OSiMe}_{3}=0.74 \mathrm{kcal} / \mathrm{mol}$ ), presumably because the 
$\mathrm{SiR}_{3}$ group can be turned away to avoid the steric interaction. ${ }^{18}$ This explains the loss of $\pi$ facial selectivity in our substrate. As separation of the diastereoisomers was not easy, we revised our strategy and decided to use compound $\mathbf{2 5}$ as a new fragment for the $\mathrm{C} 1-\mathrm{C} 12$ segment in which the $\mathrm{C} 11$ methyl stereogenic center is preinstalled (Scheme 5). Instead of coupling the 1,3-diene iodide fragment 3 to $(B)$-alkylborane (derived by hydroboration from fragment 4), we decided to couple it to the ate complex 26 derived from the corresponding iodide easily accessible from compound $\mathbf{2 5}$ in two steps. ${ }^{19}$ Preliminary studies involving ( \pm )alkenyliodide fragment 3 and a model alkyl boronate to assemble the 1,3-diene corroborate the feasibility of this strategy. 20

The synthesis of compound $\mathbf{2 5}$ commenced with isoprene monoxide (Scheme 6). $\mathrm{TiCl}_{4}$ mediated regioselective and stereoselective opening of the epoxide provided the alcohol, which was protected as a TIPS ether $\mathbf{2 8}$. It was then coupled with propargylmagnesium bromide in the presence of $\mathrm{Pd}-\left(\mathrm{PPh}_{3}\right)_{4}$ to give acetylene $\mathbf{2 9}$ in $83 \%$ yield. In parallel, aldehyde $\mathbf{3 1}$ was synthesized in two steps via the Wittig reaction, followed by reduction with $i-\mathrm{Bu}_{2} \mathrm{AlH}$. The key strategy is to employ asymmetric addition of alkenylzinc to aldehyde $\mathbf{3 1}$ in the presence of Nugent's ${ }^{21}$ isoborneol-based (-)-MIB ligand. ${ }^{22}$ Hydroboration of the terminal acetylene 29 with freshly prepared dicyclohexylborane proceeds regio-selectively to afford the alkenylborane. Transmetalation of this alkenylborane with $\mathrm{Me}_{2} \mathrm{Zn}$ generates the reactive alkenylzinc reagent in situ. Attempts to carry out the transmetalation at $0{ }^{\circ} \mathrm{C}$, as described in the literature, ${ }^{23}$ led to decomposition of the substrate. After extensive experimentation, we found that the reaction could be performed successfully by adding $\mathrm{Me}_{2} \mathrm{Zn}$ followed by (-)MIB at $-78{ }^{\circ} \mathrm{C}$ to alkenylborane. The mixture was then warmed to $-20^{\circ} \mathrm{C}$ over $10 \mathrm{~min}$. The aldehyde 31 in hexane was added via syringe pump over 20 min while warming the mixture to $0{ }^{\circ} \mathrm{C}$ to furnish divinyl methanol $\mathbf{3 2}$ in $43 \%$ yield and $\geq 95 \%$ diastereomeric excess (de). This assembled the full carbon backbone of compound $\mathbf{2 5}$. The next challenge was to functionalize stereoselectively the C7-C8 double bond of this unsymmetrical divinyl methanol $\mathbf{3 2}$.

It is documented that the simple ( \pm )-unsymmetrical divinyl methanols can be subjected to the Sharpless kinetic resolution conditions to synthesize the optically active monoepoxide. ${ }^{24}$

However, to the best of our knowledge, Sharpless asymmetric epoxidation has not been applied to desymmetrize a complex unsymmetrical divinyl methanol such as ours in the context of natural product synthesis. We were pleased to find that Sharpless' asymmetric epoxidation provided the $\mathrm{C} 7-\mathrm{C} 8$ monoepoxide in $71 \%$ yield $(6: 1 \mathrm{dr})$. TIPS protection went uneventfully to furnish $\mathbf{2 5}$ in $90 \%$ yield.

In conclusion, we have accomplished the synthesis of three fragments, $\mathbf{2 , 3}$ and, $\mathbf{4}$. Compound 25 will be used as the new fragment for the C1-C12 segment. 1,3-Isomerization of allylic alcohol via rhenium oxo catalysis has been applied successfully in our synthesis. (-)-MIBcatalyzed asymmetric vinylzinc addition to aldehyde 31, highly selective late-stage epoxidation of divinyl methanol 32, and regio- and stereo-selective silylstannylation to synthesize stannane 20 have been used as key steps. Continued advancement of these intermediates toward the eventual total synthesis of $\mathbf{1}$ are currently ongoing in our laboratory.

\section{Acknowledgment}

We gratefully acknowledge financial support from NIH (GM062120). J.S.S. acknowledges the American Chemical Society, Division of Medicinal Chemistry, and Aventis Pharmaceuticals for a pre-doctoral fellowship.

\section{References}

1. Ishibashi M, Ohizumi Y, Hamashima M, Nakamura H, Hirata Y, Sasaki T, Kobayashi J. J. Chem. Soc., Chem. Commun 1987:1127.. For reviews: (a) Kobayashi J, Ishibashi M. Chem. Rev 1993;93:1753. (b) Chakraborty T, Das S. Curr. Med. Chem.: Anti-Cancer Agents 2001;1:131. (c) Kobayashi J, 
Shimbo K, Kubota T, Tsuda M. Pure Appl. Chem 2003;75:337. (d) Kobayashi J, Tsuda M. Nat. Prod. Rep 2004;21:77. [PubMed: 15039836]

2. Kobayashi J, Ishibashi M, Nakamura H, Ohizumi Y, Yamasu T, Hirata Y, Sasaki T, Ohta T, Nozoe S. J. Nat. Prod 1989;52:1036. [PubMed: 2607346]

3. (a) Kobayashi J, Tsuda M. Nat. Prod. Rep 2004;21:77. [PubMed: 15039836] (b) Cid MB, Pattenden G. Synlett 1998:540. (c) Cid MB, Pattenden G. Tetrahedron Lett 2000;41:7373. (d) Ishiyama H, Takemura T, Tsuda M, Kobayashi J. Tetrahedron 1999;55:4583. (e) Ishiyama H, Takemura T, Tsuda M, Kobayashi J. J. Chem. Soc., Perkin Trans 1999;1:1163. (f) Ohi K, Shima K, Hamada K, Saito Y, Yamada N, Ohba S, Nishiyama S. Bull. Chem. Soc. Jpn 1998;71:2433. (g) Ohi K, Nishiyama S. Synlett 1999:573. (h) Ohi K, Nishiyama S. Synlett 1999:571. (i) Chakraborty TK, Thippeswamy D, Suresh VR, Jayaprakash S. Chem. Lett 1997:563. (j) Chakraborty TK, Thippeswamy D. Synlett 1999:150. (k) Chakraborty TK, Thippeswamy D, Jayaprakash S. J. Ind. Chem. Soc 1998;75:741. (l) Chakraborty TK, Suresh VR, Vayalakkada R. Chem. Lett 1997:565. (m) Eng HM, Myles DC. Tetrahedron Lett 1999;40:2275. (n) Eng HM, Myles DC. Tetrahedron Lett 1999;40:2279. (o) Lee D-H, Lee S-W. Tetrahedron Lett 1997;38:7909. (p) Lee D-H, Rho M-D. Bull. Korean Chem. Soc 1998;19:386. (q) Lee D-H, Rho M-D. Tetrahedron Lett 2000;41:2573. (r) Zhang W, Carter RG, Yokochi AFT. J. Org. Chem 2004;69:2569. [PubMed: 15049660]

4. Mandal AK, Schneekloth JS Jr, Crews CM. Org. Lett 2005;7:3645. [PubMed: 16092840]

5. Miyaura N, Ishiyama T, Sasaki H, Ishikawa M, Satoh M, Suzuki A. J. Am. Chem. Soc 1989;111:314.

6. Evans DA, Carter PH, Carreira EM, Charette AB, Prunet JA, Lautens M. J. Am. Chem. Soc 1999; $121: 7540$.

7. Brown HC, Bhat KS. J. Am. Chem. Soc 1986;108:293.

8. (a) Takahashi H, Kawakita T, Ohno M, Yoshioka M, Kobayashi S. Tetrahedron 1992;48:5691. (b) Kitamoto D, Imma H, Nakai T. Tetrahedron Lett 1995;36:1861.

9. (a) Schmidt B, Seebach D. Angew. Chem., Int. Ed. Engl 1991;30:99. (b) von dem Bussche-Hunnefeld JL, Seebach D. Tetrahedron 1992;48:5719.

10. Schoop T, Roesky HW, Noltemeyer M, Schmidt H-G. Organometallics 1993;12:571.

11. Bellemin-Laponnaz S, Gisie H, Le Ny J-P, Osborn JA. Angew Chem., Int. Ed. Engl 1997;36:976.

12. Walsh PJ, Sharpless KB. Synlett 1993:605.

13. Ashimori A, Bachand B, Calter MA, Govek SP, Overman LE, Poon DJ. J. Am. Chem. Soc 1998;120:6488.

14. Gao Y, Hanson RM, Klunder JM, Ko SY, Masamune H, Sharpless KB. J. Am. Chem. Soc 1987;109:5765.

15. (a) Mitchell TN, Wickenkamp R, Amamria A, Dieke R, Scheider U. J. Org. Chem 1987;52:4868. (b) Chenard BL, Van Zyl CM. J. Org. Chem 1986;51:3561.

16. Reetz MT, Kesseler K. J. Org. Chem 1985;50:5434.

17. Evans DA, Bartroli J, Godel T. Tetrahedron Lett 1982;23:4577.

18. Eliel, EL.; Wilen, SH.; Mander, LN. Stereochemistry of Organic Compounds. New York: John Wiley \& Sons; 1993. p. 696

19. Miyaura N, Suzuki A. Chem. Rev 1995;95:2457.

20. Unpublished results

21. Nugent WA. J. Chem. Commun 1999:1369.

22. (a) Oppolzer W, Radinov RN. Hev. Chim. Acta 1992;75:170. (b) Pu L, Yu H-B. Chem. Rev 2001;101:757. [PubMed: 11712502]Review:

23. Chen YK, Lurain AE, Walsh PJ. J. Am. Chem. Soc 2002;124:12225. [PubMed: 12371863]

24. Honda T, Mizutani H, Kanai K. J. Chem. Soc., Perkin Trans. 1 1996;14:1729. 


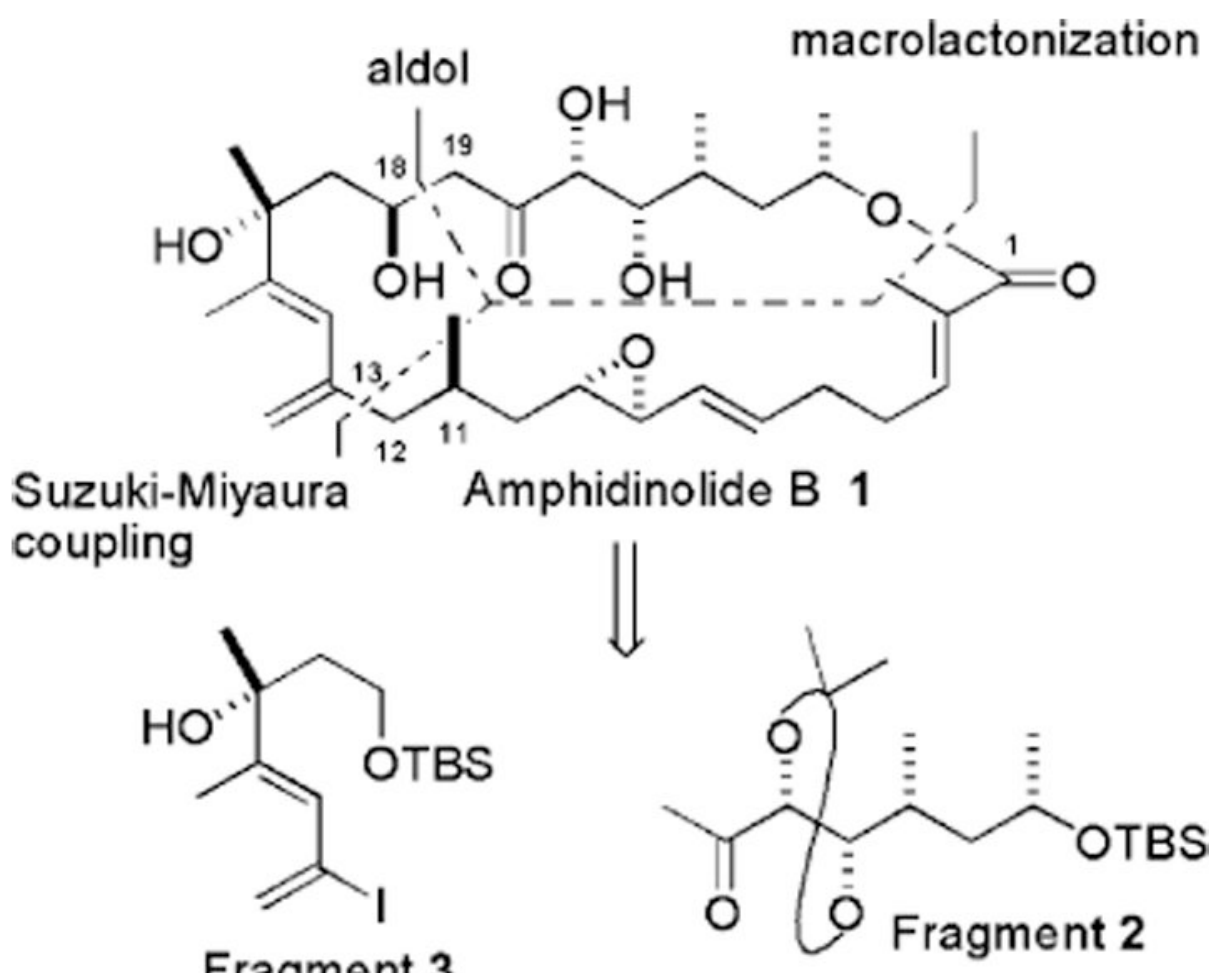

Fragment 3

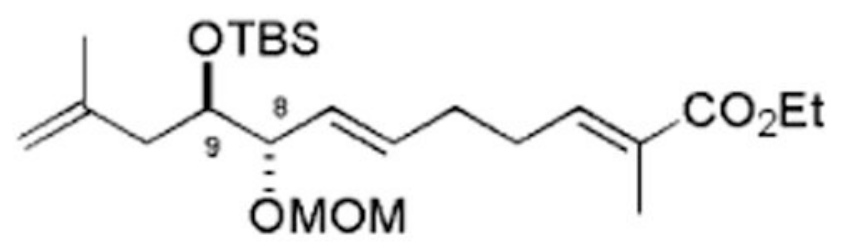

Fragment 4

Scheme 1. 

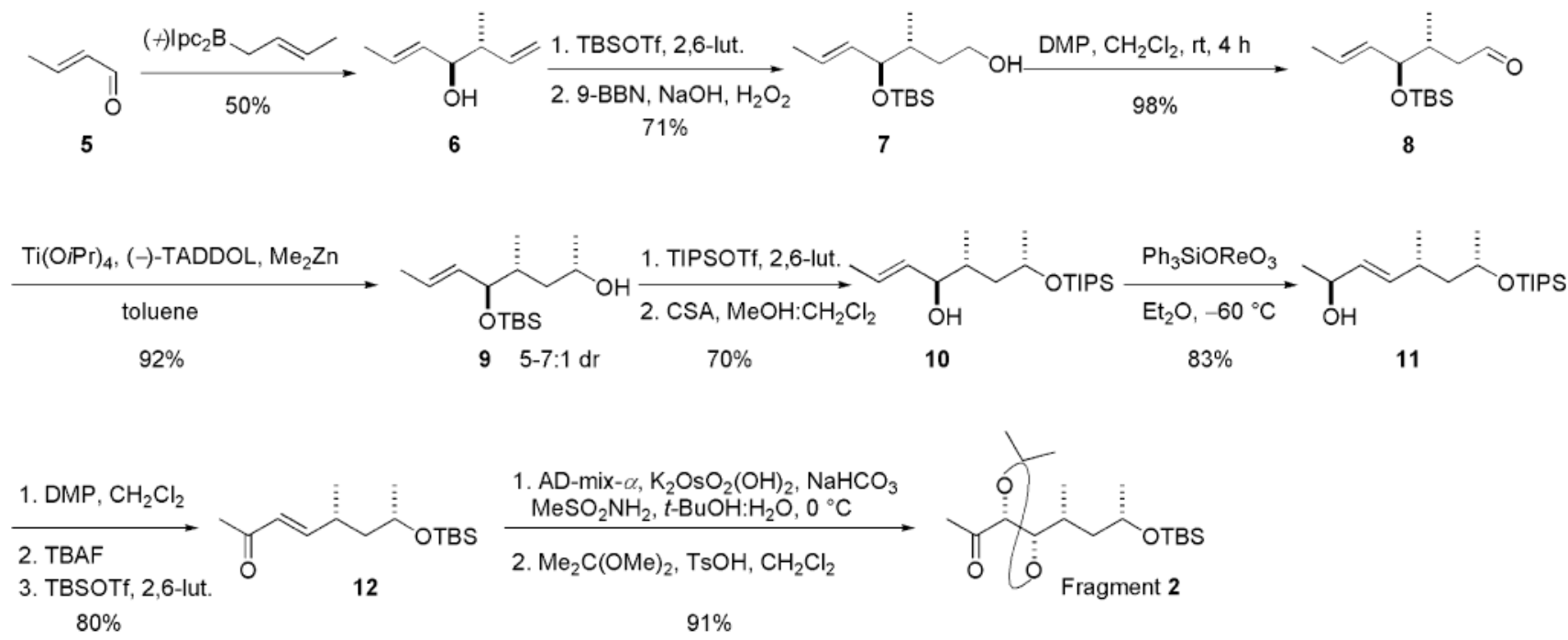

Scheme 2. 


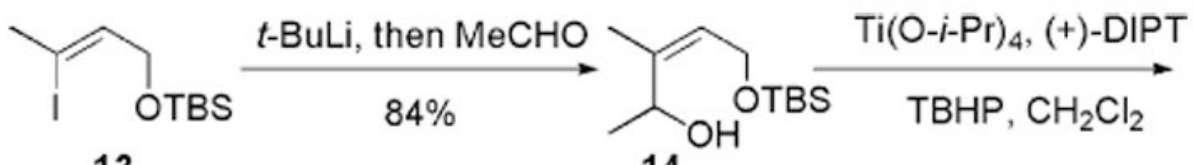

13

14
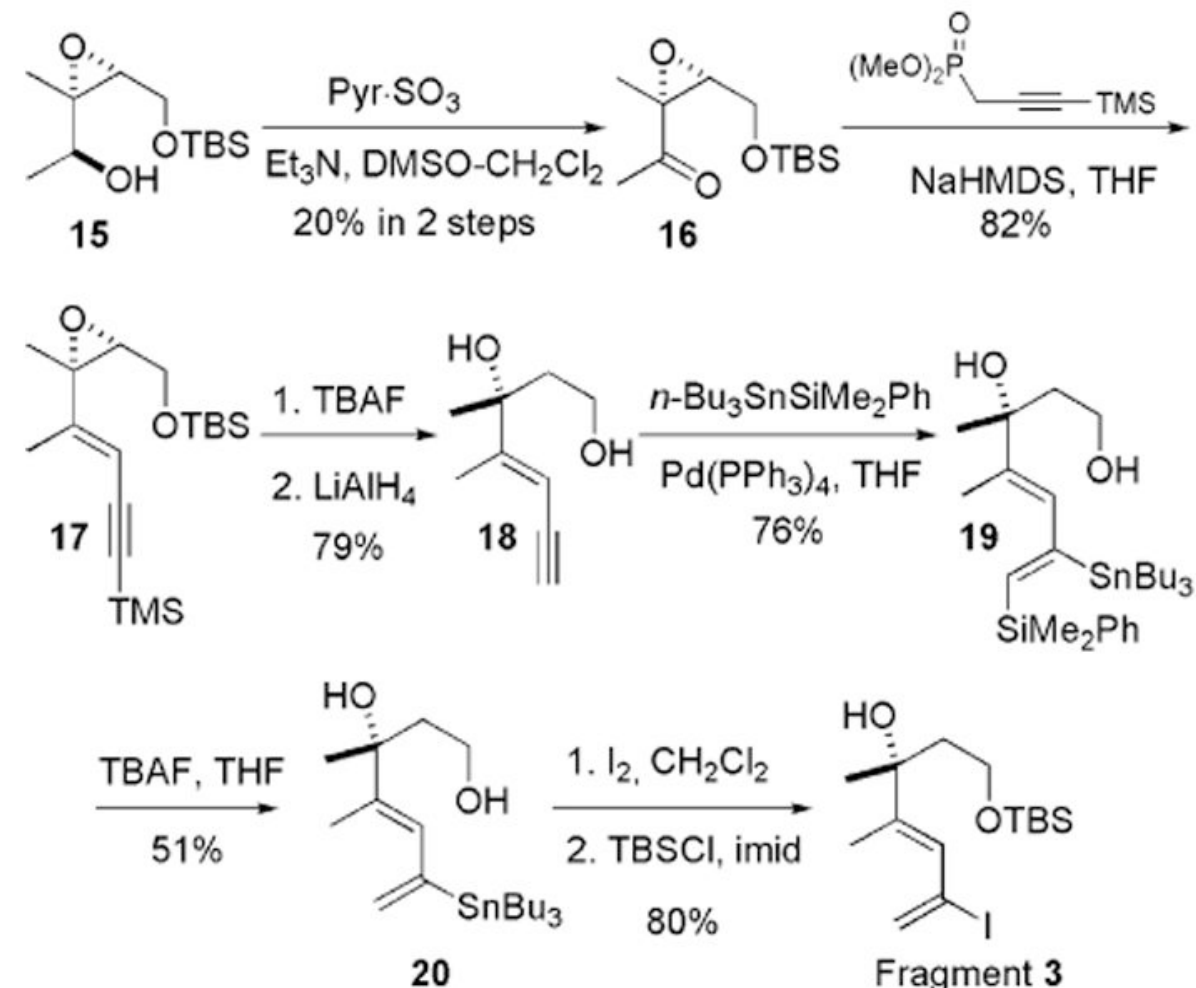

Scheme 3. 


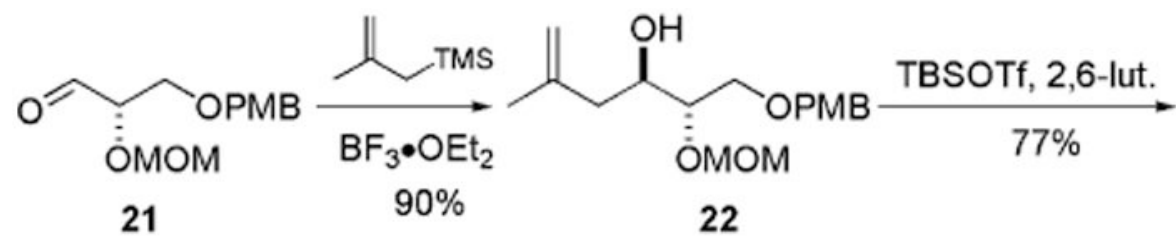

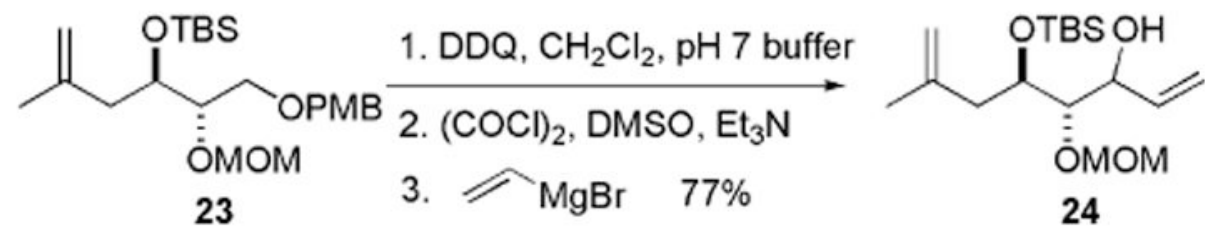

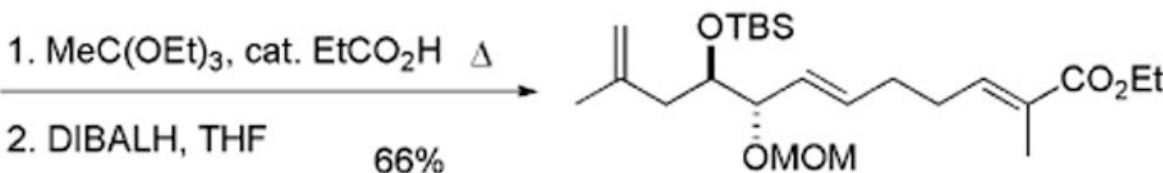

3.<smiles>CCOC(=O)C(C)=Pc1ccccc1</smiles>

Fragment 4

Scheme 4. 


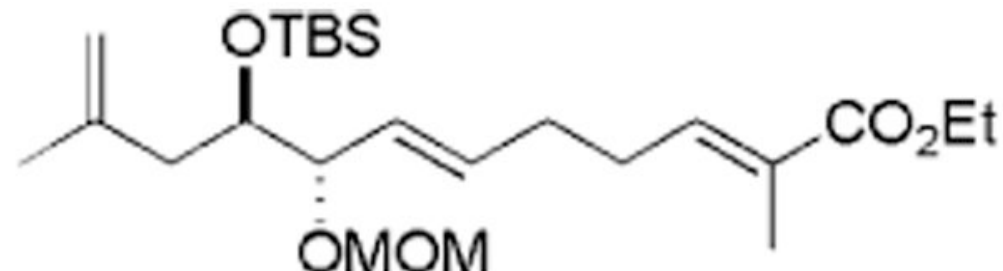

Fragment 4
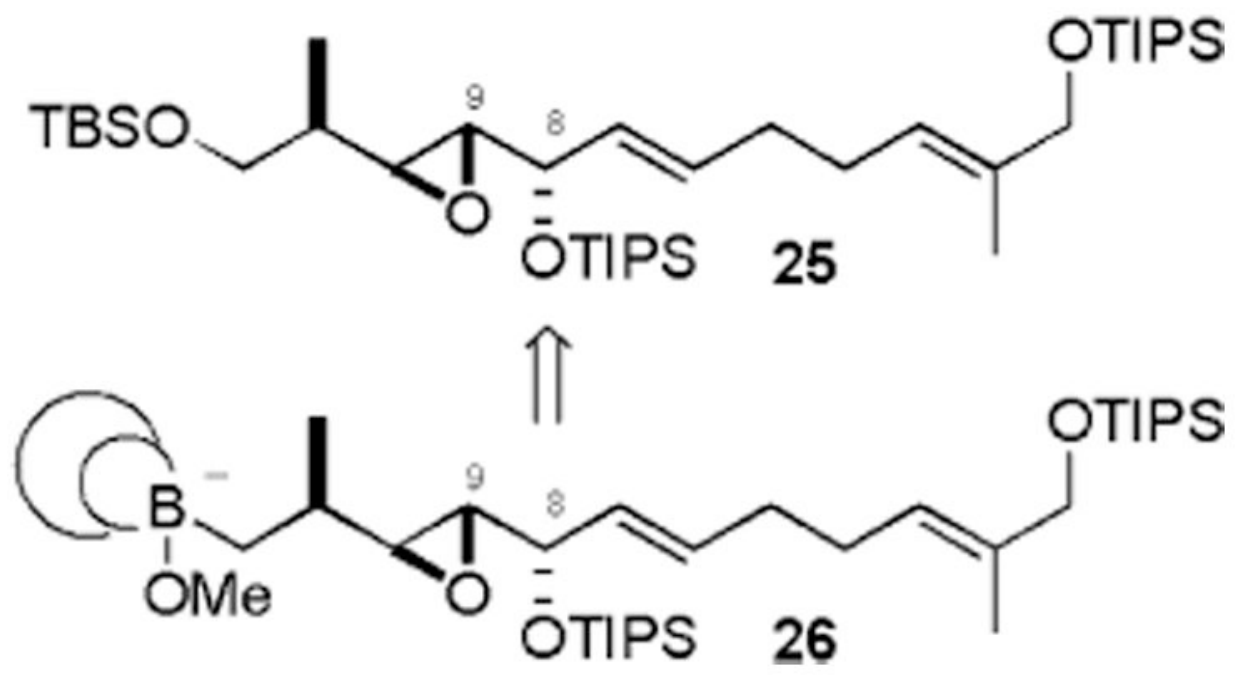

Scheme 5. 


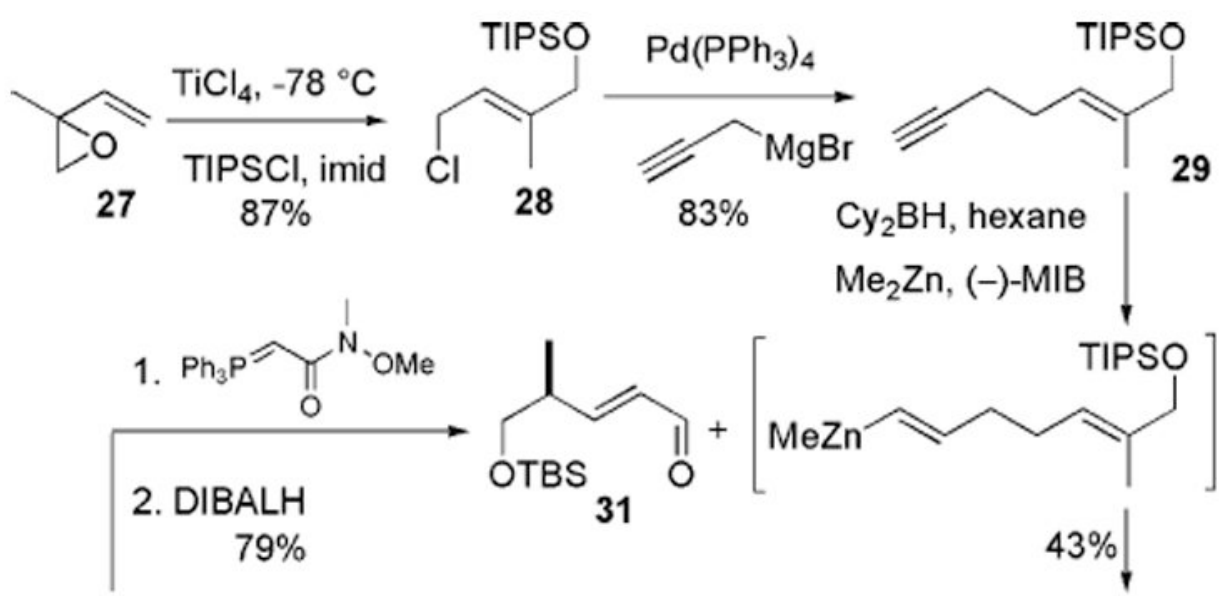<smiles>CC(C=O)C[Se-]S(=O)(=O)c1ccccc1</smiles><smiles>CC1(C)CC2CCC1C(N1CCOCC1)C2O</smiles>

(-)-MIB

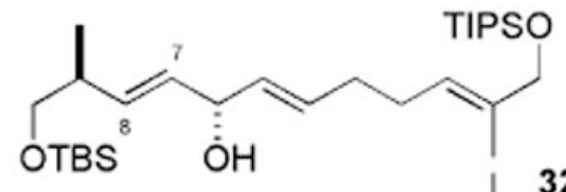

1. $\mathrm{Ti}(\mathrm{O}-i-\mathrm{Pr})_{4},(+)-\mathrm{DIPT}$ TBHP, $\mathrm{CH}_{2} \mathrm{Cl}_{2},-20^{\circ} \mathrm{C} \quad 63 \%$

2. TIPSOTf, 2,6-lut.

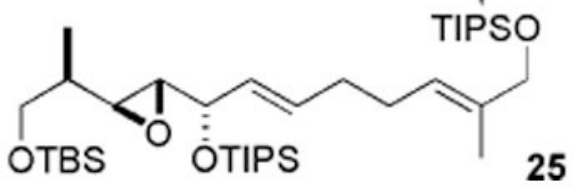

Scheme 6. 